This is an Accepted Manuscript of an article published by Taylor \& Francis Group in Theology and Science in May 2013, available online:

http://www.tandfonline.com/doi/full/10.1080/14746700.2013.780432\#abstract.

\title{
Hegel and Whitehead: In Search of Sources of the Contemporary Versions of Panentheism in the Science/Theology Dialogue
}

\author{
Mariusz Tabaczek, O.P.
}

\begin{abstract}
Panentheism has recently become a widely accepted and appreciated concept among scholars in the science-theology dialogue, and its theological repercussions have been discussed to great extent. Yet, there remains to be studied in more detail the notion of the philosophical foundations of the term. A prominent gap in our understanding of these foundations is the potential similarity between the metaphysics of Hegel and Whitehead, their understanding of the transcendence and immanence of God, and their respective versions of panentheism. In this article, I present a critical reflection on the possible resemblance between process thought and Hegelian metaphysics and philosophy of God. In the last section I refer to those who use panentheism within the science-theology dialogue. I try to specify which of the two versions of panentheism, that of Hegel or Whitehead, is more popular among those scholars.
\end{abstract}

\section{Keywords}

Panentheism, Hegel, Whitehead, Transcendence, Immanence 


\section{Introduction}

That 'panentheism' has recently become a widely accepted and appreciated concept among scholars who committed themselves to the science/theology debate within the Anglo-American context is clear and undeniable. Ian Barbour, Philip Clayton, Paul Davies, Arthur Peacocke, and Keith Ward are some key figures supporting the claim that it is the concept of the world being 'in' God (pan-en-Theos), who at the same time surpasses it, that enables us to find a third way between classical theism and pantheism. They all use panentheism to depict and explain a new model of divine action and a theological understanding of the processes and interactions occurring in the world described by natural sciences.

Because of its reference to the God-world relationship, panentheism tends to be regarded a purely theological concept. But it is not. Its origins are in philosophy and go back to Plato and Neoplatonism. Transmitted by Pseudo-Dionysius, John Scotus Eriugena and Nicholas of Cusa, panentheism found new expression in German Idealism. It was within this philosophical tradition that the very term 'panentheism' (Allingottlehre) was coined (K.C.F. Krause) and the metaphysical shift from substance to subject found its culmination (G.W. Hegel). ${ }^{1}$ God expressing or unfolding himself in the world is understood as the Creator who remains in a dynamic reciprocity with creation. This expressivist version of philosophical panentheism became a source of theological panentheistic propositions presented in the contemporary science/theology debate. ${ }^{2}$

But there is one more crucial point of reference for many of those who adopt philosophical panentheism, namely Whitehead's philosophy of process. Built within the Whitehedian process framework, Charles Hartshorne's concept of a dipolar God

\footnotetext{
${ }^{1}$ To find more about the historical panentheism and its representatives go to John W. Cooper, Panentheism. The Other God of the Philosophers (Grand Rapids, Michigan: Baker Academic, 2006). The roots of the contemporary version of panentheism are also described by Michael W. Brierley in his article "Naming a Quiet Revolution: The Panentheistic Turn in Modern Theology," in In Whom We Live and Move and Have Our Being. Panentheistic Reflections on God's Presence in a Scientific World, edited by Philip Clayton and Arthur Peacocke (Grand Rapids, Michigan/Cambridge, U.K.: William B. Eerdmans Publishing Company, 2004), 13.

${ }^{2}$ See Philip Clayton, God and Contemporary Science (Grand Rapids: Eerdmans Publishing Company, 1997), 94,245; Philip Clayton, "Panentheism in Metaphysical and Scientific Perspective," in In Whom We Live and Move and Have Our Being, 79-81; Keith Ward, "The World as the Body of God," in In Whom We Live and Move and Have Our Being, 64-7.
} 
influenced not only John Cobb and David Griffin who applied it to postmodern theology and social justice issues. It turned out to be inspiring also for those trying to bridge science and religion. Barbour, Clayton and Ward make a clear reference to the philosophy of process. ${ }^{3}$ Although Peacocke distances himself from this tradition, his concept of transcendence-in-immanence and his understanding of the God-world relation resemble the theology proposed by Hartshorne as well. ${ }^{4}$

After we have named two main philosophical sources of contemporary panentheism, the question should be asked whether they are complementary or distinctive. Does the Whitehedian dipolar notion of God resemble expressivist Hegelian Panentheism? Is there a relation between these two synoptic thinkers in the tradition of western philosophy? The case is problematic. There are thinkers, who - following Robert Ellis - claim, that we should not treat Whitehead as "a sort of Melchizedek of twentiethcentury philosophy - arriving on the scene to bless Abrahams and slay other warriors without ancestry and obvious philosophical lineage." ${ }^{5}$ For them Whithehead's dependence on German and British Idealism is undeniable. On the other hand, however, there are scholars who tend to support the opposite position expressed by Victor Lowe who says: "Only in his metaphysics - particularly in his doctrine of coherence - is a Hegelian influence notable. Had there never been a Hegel, (...) Whitehead would still have been led to that [doctrine] by his instinctive acknowledgement that the truth is complex, and that different thinkers have got hold of contrasting aspects of it." ${ }^{6}$ This position appears to be in agreement with Whitehead himself, who said at one point: "I have never been able to read Hegel: I initiated my attempt by studying some remarks of his on mathematics which struck me as complete nonsense. It was foolish of me, but I am not writing to explain my good sense."

\footnotetext{
${ }^{3}$ See Ian G. Barbour, Religion and Science. Historical and Contemporary Issues, (New York: Harper Collins Publishers, 1997), chapters 11: Process Thought, and 12: God and Nature; Philip Clayton, God and Contemporary Science, 94; Keith Ward, The World as the Body of God, 67-71.

${ }^{4}$ See Robert John Russell, "The theological-scientific vision of Arthur Peacocke," Zygon 26, no. 4 (December 1991), 512.

${ }^{5}$ Robert Ellis, "From Hegel to Whitehead," Journal of Religion 61, no. 4 (Oct. 1981), 403.

${ }^{6}$ Victor Lowe, Understanding Whitehead (Baltimore: The Johns Hopkins Press, 1966), 257.

${ }^{7}$ Alfred North Whitehead, Essays in Science and Philosophy (London: Rider \& Co., 1948), 10.
} 
As one can see, different scholars seem to support opposite positions, which shows the need for clarifying the problem. The first part of this article is a critical appraisal of the debate on similarities and possible relations between Hegel and Whitehead's philosophical method and metaphysics. In the second part I compare their respective versions of panentheism. Finally, in the last chapter, I refer to those who use panentheism within the framework of the science/theology dialogue in the Anglo-American context. I investigate the question to see which of those two sources of panentheism is more popular among those scholars.

\section{Similarities and differences}

It appears to me that George Lucas is right when he says that comparing Hegel and Whitehead one can discover and name a deep difference and division between European and Anglo-American philosophy. Those who practice the analytic and critical method in the Anglo-American context tend to be in a sharp contrast with advocates of a more systematic, synoptic and speculative European tradition. ${ }^{8}$ However, there is a whole group of thinkers (including Lucas) who claim that the Whitehedian metaphysical perspective appears Hegelian in many respects. In what follows I examine critically some major similarities between the two philosophers in terms of their method and metaphysics.

\subsection{System Builders}

The first characteristic that can be regarded as a common feature of Hegel's and Whitehead's philosophy is their attempt to build a philosophical system. They are both interested in 'organic wholeness'. For many contemporary philosophers, such an endeavor is a sign of arrogance and boldness. Any pretense of finality and totality is rather disregarded at the time when new theories are expected and accepted only within narrow and specialist branches of knowledge of any kind. On the other hand, however, such holistic attitude in philosophy seems to be more legitimate in the age of science, which -

\footnotetext{
${ }^{8}$ George R. Lucas, "Hegel, Whitehead, and the Status of Systematic Philosophy," in Hegel and Whitehead. Contemporary Perspectives on Systematic Philosophy, edited by George R. Lucas, JR (New York: State University of New York Press, 1986), 3.
} 
although specialized - still tends to present physical and biological theories that would explain the structure of the whole universe and all living organisms on the earth. ${ }^{9}$

Hegel's metaphysics is rooted in the concept of Idea (Spirit, God) unfolding itself in creation, Nature and human beings. For him, totality as a matter of interrelatedness is a function of the infinite Spirit. An outline of Hegel's dialectic proposed by Sprigge helps us to realize that the Hegelian metaphysical project is applicable to an understanding of history, politics, culture, sociology, psychology, anthropology, epistemology, aesthetics, ethics and religion. The explanatory power of Hegelian dialectic is remarkable. Thus Hegel himself can be regarded a system builder. ${ }^{10}$

Whitehead's approach appears to be radically different from Hegel's, at least at the first sight. For one would expect that any notion of finality or totality should rather be rejected by any proponent of the philosophy of process, which presupposes a ceaseless flux of changes. Indeed, in the preface to Process and Reality Whitehead says: "In philosophical discussion, the merest hint of dogmatic certainty as to finality of statement is an exhibition of folly." But the truth is that Whitehead's intentions are by no means as humble as he assures us. In the same preface he claims that his purpose is to "state a condensed scheme of cosmological ideas, to develop their meaning by confrontation with the various topics of experience, and finally to elaborate an adequate cosmology in terms of which all particular topics find their interconnections." ${ }^{\prime 2}$ This statement can be regarded as an aspiration to totality. Whitehead's philosophy is the 'philosophy of organism'. He may not refer to other fields of human knowledge and self-understanding. But it is clear that for him all that is and can be known is a part of one organism which is in the state of permanent growth and development. This notion permeates the whole Process and Reality.

\footnotetext{
${ }^{9}$ See Errol E. Harris, "The Contemporary Significance of Hegel and Whitehead," in Hegel and Whitehead, 17; George L. Kline, "Concept and Concrescence: An Essay in Hegelian-Whitehedian Ontology," in Hegel and Whitehead, 133.

${ }^{10}$ T. L. S. Sprigge, The God of Metaphysics (Oxford: Clarendon Press, 2006), 114-55. See also Michael Forster, "Hegel's Dialectical Method," in The Cambridge Companion to Hegel, edited by Frederick C. Beiser (New York, Cambridge: Cambridge University Press, 1993), 130-70.

${ }^{11}$ Alfred North, Whitehead, Process and Reality (New York: The Free Press, 1985), xiv.

${ }^{12}$ Ibid., xii.
} 
That is why I claim that Whitehead's attempt to construct a cosmological system is similar to Hegel's dialectic project with its wide scope of explanatory power. At this point I side with Van der Veken who classifies Whiteheadian speculative philosophy as a more humble form of Hegelianism. I also agree with Welker when he says that both philosophers are similar to each other in their effort to construct universal "contact theories' designed to mediate between heterogeneous realms of cultural experience."13

\subsection{Metaphysical Principle}

After this general statement about the systematic character of Hegel and Whitehead's philosophy, we should now turn our reflection to the most crucial question in every metaphysics. What is the basic metaphysical principle of the universe? What is reality made of? It seems that answering this question Hegel and Whitehead might share some common ideas.

Trying to understand Hegel's concept of the organization of reality, one must go back to the history of Spinozism. It is inevitable, because Hegel - pursuing another attempt to overcome the mind/body (subjective/objective) dualism - proposes an idealistic metaphysics of substance, and thus places himself, along with Schelling, among the heirs of Spinoza's idea of One Substance. However, this common starting point would eventually bring those two close friends to a profound disagreement. Schelling's Absolute, understood as a unifying principle, seems to be conceived as the indifference of the subjective and the objective. Yet Hegel's idea of the Spirit unfolding itself through the dialectical juxtaposition can also bring the unity between the subjective and the objective, but it is possible only through the emphasis on the disparity between the two. ${ }^{14}$

It was at this point that Hegel rejected the static notion of Spinoza's One Substance, replaced it by 'Subject', and thus offered a new answer to the question of the

\footnotetext{
${ }^{13}$ Michael Welker, "Hegel and Whitehead: Why Develop a Universal Theory?," in Hegel and Whitehead, 12728; Jan Van der Veken, "A Plea for an Open, Humble Hegelianism," in Hegel and Whitehead, 109-10.

${ }^{14}$ Hegel's critique of Spinoza is to be found in Lectures on the History of Philosophy Vol. III, translated by E. S. Haldane and Frances H. Simson. London, (Routledge \& Kegan Paul LTD, 1955), 263-64, 280-83, 287-88; Logic, translated by William Wallace (Oxford: Clarendon Press, 1894), 89-90, 236-7, 317. See also HansChristian Lucas, "Spinoza, Hegel, Whitehead: Substance, Subject, and Superject," in Hegel and Whitehead, 41-2.
} 
metaphysical principle of the universe. The Hegelian Substance (Idea, Spirit, God) is a duality of sameness and otherness (subjectivity and objectivity). It is singular and plural (universal) at once, and for this reason it is not isolated from individual beings. Reality is an expression of the Absolute Spirit which unfolds itself in the perpetual flux of dialectical process. The hiatus between One Substance and its modes in Spinoza's metaphysics is overcome. Substantiality is developed into subjectivity. ${ }^{15}$

Similar to Hegel, Whitehead is also aware that his organic doctrine is "close to Spinoza; but - as he says - Spinoza bases his philosophy upon the monistic substance, of which the actual occasions are inferior modes. The philosophy of organism inverts this point of view." ${ }^{\prime 16}$ Whitehead appreciates Spinoza for beginning with one substance (unlike Descartes), but at the same time emphasizes an advance of his own metaphysic in which the "'substance-quality' concept is avoided, (...) morphological description is replaced by description of dynamic process, (...) Spinoza's 'modes' now become the sheer actualities."17 For Whitehead, reality is a process of becoming of actual entities which he describes as basic units, 'puffs of existence'. They become objectified in other actual entities through prehension. Thus relatedness is one of the main characteristics of the philosophy of organism. ${ }^{18}$

This analysis shows some important similarities between the two philosophers. They perceive reality as a process of becoming and transcend substance into the dynamic subject. Lucas rightly points out that for both of them Spinoza's concept of causa sui becomes a useful category in describing the 'ontological principle'. Hegel's dialectic, in which 'substance-subject' releases attributes out of itself, resembles Whitehead's actual entity which "is at once the product of the efficient past, and is also, in Spinoza's phrase,

\footnotetext{
${ }^{15}$ In the Preface to The Phenomenology of the Mind Hegel says that "everything depends on grasping and expressing the ultimate truth not as Substance but as Subject as well." See Georg Wilhelm Hegel, The Phenomenology of Mind, translated by J.B. Baillie (London: George Allen \& Unwin LTD, 1931), 8o. See also Hans-Christian Lucas, Spinoza, Hegel, Whitehead, 40-6.

${ }^{16}$ Whitehead, Process and Reality, 81.

${ }^{17}$ Ibid., 7 .

${ }^{18}$ Lucas, Spinoza, Hegel, Whitehead, 46-9.
} 
causa sui." ${ }^{19}$ It means that each actual occasion is a cause of the final stage of its own concrescence.

On the other hand, however, one should not ignore some major differences between Hegel and Whitehead in their reinterpretation of Spinozism, and their shaping new metaphysical propositions. Though unfolding dialectically into many entities, the Hegelian Subject (Spirit) is one, and his metaphysics can be classified as idealistic monism. Contrary to this concept, Whiteheadian actual entities are many. Although they remain in the unity of relatedness, Whitehead's metaphysics is an example of pluralism. It can be also classified as another version of atomism, but this time it is an atomism that is balanced with continuity. Whitehead explains that the contradiction between the two terms is solved in a way similar to the physical description of both the corpuscular and the wave nature of light. ${ }^{20}$

The other difference between Hegel and Whitehead refers to finality and purposefulness. While Hegel regarded his dialectical unfolding of the Spirit in nature a purposive activity heading toward the finality of existing 'Real', Whitehead's process of concrescence has neither finality nor purpose other than the enjoyment of each particular actual occasion and God (the chief exemplification of actual occasions).

\subsection{Dialectic and Process}

Foregoing the comparison of Hegel and Whitehead's understanding of ontological principle of the universe remains incomplete and poses another crucial question. It refers to the very heart of their metaphysical systems, namely, the mechanics of Hegelian dialectics and Whitehedian process. Are they equivalent descriptions of the same 'mechanism'?

Some experts find a deep resemblance between Hegel's dialectic and Whitehead's process, and their claims seem to be justified. R. Whittemore says that, although not synonymous, both terms are deeply related. ${ }^{21}$ E. Harris, beginning with the analysis of

\footnotetext{
${ }^{19}$ Whitehead, Process and Reality, 150; Lucas, Spinoza, Hegel, Whitehead, 45, 48.

${ }^{20}$ Whitehead, Process and Reality, 36.

${ }^{21}$ Robert C. Whittemore, "Hegel's 'Science' and Whitehead's 'Modern World'," Philosophy 31, no. 116 (Jan. 1956), 44-5.
} 
Whitehead's process of concrescence within the individual actual entity, extends its mechanism to the prehension by the whole generation of actual occasions, and lists its phases: dative ingression, conformal physical feeling, conceptual feeling and comparative feeling. According to his view, the first two phases merge into one, and the whole mechanism resembles the Hegelian dialectical triad: immediacy, distinction and differentiation, and articulated synthesis. ${ }^{22}$ He says that although "Whitehead nowhere gives as explicit an account of the method of process as does Hegel, (...) in what he does say about it we can recognize most of the important features of dialectic". The key one consists in the fact that "process is one of self-realisation of subjective unity." 23

I find Harris' argument questionable. For the difference between Hegel and Whitehead in their understanding of 'subjective unity' is considerable. The former develops a 'macro' ontology of the universal subjective unity (Spirit), whereas the latter builds a 'micro' ontology made of atoms of subjective unity (actual occasions). The Hegelian Spirit posits itself in Nature and Human. Proceeding from unity to plurality, it eventually reverts to the unity of the finitely existing 'Real'. It is questionable that Whitehead's process is based on the same mechanics. One may say that in the process of prehension actual occasions pass from unity to plurality just as the Hegelian Spirit. The process of concrescence begins with their reference to past actual occasions and lures of novelty presented to them in 'eternal objects'. But this assertion brings to discussion another important issue, namely, the role and character of negation in dialectic and process.

It appears that there are three possible definitions of what we could regard an equivalent of Hegel's dialectical antithesis in Whitehead's philosophy of organism. The first one has been already described above. In this view, an actual occasion is a thesis, prehension an antithesis, the final stage of concrescence a synthesis. Negation consists of an actual occasion's reference to all past occasions and future possibilities given in eternal objects. But does prehension really resemble dialectical negation? The Hegelian antithesis is not a random reference to past or future beings. Thesis and antithesis must be somehow

\footnotetext{
${ }^{22}$ Harris, The Contemporary Significance, 24.

${ }^{23}$ Ibid., 23.
} 
related (e.g. a negation of intuition is a sensual representation, instinctive desire is opposed to self-conscious recognition). Whitehead's prehension does not meet this requirement (actual occasion can prehend all kinds of data given in past occasions and various eternal objects).

The second possible interpretation of negation in Whitehead's philosophy is problematic for the same reasons. Harris claims that it is not prehension but rather 'negative prehension' that serves as dialectical negation in the process of concrescence of an actual occasion. 'Negative prehension' is a "definite exclusion of [a certain] item from the positive contribution to the subject's own real internal construction." ${ }^{24}$ But again, is the excluded 'item' related to prehending actual occasion? Or is it chosen randomly? ${ }^{25}$

The third attempt to clarify the sense of negativity in Whitehead's metaphysics was presented by Gregory Vlastos, who distinguishes homogenous (logical) and heterogeneous dialectic. The former one is found in Hegel for whom all three stages of the dialectical triad "are ontologically homogeneous. Thesis, antithesis, and synthesis are all of the nature of Idea." ${ }^{26}$ Unlike that of Hegel, Whitehead's dialectic is heterogeneous. Vlastos says that in the philosophy of organism thesis is material (physical), whereas antithesis is ideal (conceptual). Because of this heterogeneity neither the second dialectical stage can be generated from the first, nor the third from the second. Thus in this version of dialectic there is no space for an internal contradiction which is essential for homogenous dialectic. Vlastos concludes that although it follows that in Whitehead's system dialectic can no longer be used as a heuristic principle, "it does not follow that it cannot be used at all. In so far as Whitehead makes use of the concept of internal relatedness, he must conserve a certain part of it: the dynamic fusion of polar opposites, the process from the abstract to the concrete. This is best shown in his basic metaphysical unit, the actual entity. Without the dialectic the actual entity can only appear (...) self-contradictory." ${ }^{27}$ This third

\footnotetext{
${ }^{24}$ Whitehead, Process and Reality, 41.

${ }^{25}$ Harris, The Contemporary Significance, 19-20. See also A. P. Ushenko, "Negative Prehension," The Journal in Philosophy 35, no. 10 (May 1937), 263-267.

${ }^{26}$ Gregory Vlastos, “Organic Categories in Whitehead," The Journal in Philosophy 35, no. 10 (May 1937), 25354 .

${ }^{27}$ Vlastos, Organic Categories in Whitehead, 254. See also Kline, Concept and Concrescence, 141-42; Klaus Hartmann, "Types of Explanation in Hegel and Whitehead." In Hegel and Whitehead, 79-80.
} 
explanation, presented by Vlastos, is the most convincing one, although the distinction he proposes still does not eliminate some important dissimilarities between Hegel's dialectic and Whitehead's process.

To sum up, one should have no doubt that there is some basic resemblance between the Hegelian dialectic and the Whitehedian process. However, a closer examination of this issue shows how many important nuances and differences emerge when the mechanics of both systems are compared. For this reason, one should be rather cautious in bringing them too easily to a common ground.

\subsection{Whitehead and the British Idealism}

At the end of this critical analysis of possible similarities between the Hegelian and Whitehedian metaphysics, I should refer one more time to Whitehead's own words quoted in the introduction. Is it right and useful at all to search for similarities between the two philosophers when one of them admits that he has never read the works of the other? Is it true that Whitehead did not know Hegel at all?

It is a fact that Whitehead hardly ever refers to Hegel in his major works. However, it has been acknowledged that he was influenced by those who represented Hegel's Absolute Idealism in Great Britain. One of key figures within this tradition - to whom Whitehead does refer in Process and Reality - is F. H. Bradley. Though he still sides with those who approve the idea of one Subject (Absolute), Bradley certainly makes a step toward the philosophy of organism with his emphasis on the primacy of feeling. For him reality is one, and it is the Absolute, which dialectically posits itself in appearances: "Reality without appearances would be nothing, for there certainly is nothing outside appearances." ${ }^{28}$ Ellis adds that for Bradley "all things are related, and a concept of true reality must include all things which are abstractions if not put in the context of the whole." ${ }^{29}$ It all naturally resembles Hegel. The originality of Bradley consists of his emphasis on the role of experience. The Absolute experiences (feels) the whole. Following Metz, Ellis calls Bradley's Absolutism the 'Absolutism of experience', as he refers to the

\footnotetext{
${ }^{28}$ F. H. Bradley, Appearance and Reality, (London: Swan Sonnenschein \& Co., 1902), 487.

${ }^{29}$ Ellis, From Hegel to Whitehead, 409.
} 
quote from Bradley: "Nothing in the end is real, but what is felt, and for me nothing in the end is real but that which I feel." ${ }^{30}$ The primacy of feeling will become the crucial point of Whitehead's metaphysics.

According to Ellis, the trajectory from Hegel, through Bradley to Whitehead has at least one more transitory stage, namely Samuel Alexander's emphasis on the inseparability of mind and things experienced..$^{31}$ Making this observation Alexander goes further and suggests that instead of one Mind (the Absolute) we should now think of many minds in a democracy of things. It is possible because "Space-Time takes for us the place which is called the Absolute in idealistic systems. It is an experimental Absolute. All finite being complexes of space-time are incomplete. They are not the sum of reality. But their absorption into One does not destroy their relative reality." ${ }^{2}$ This plurality of subjectivity is interwoven in Point-Instances (spatial points in temporal instants). Closeness to Whitehead's actual occasions is apparent and clear. ${ }^{33}$

In the preface to Process and Reality Whitehead says that although he disagrees with Bradley on many points, the final outcome of his philosophy does not differ significantly from Bradley's. ${ }^{34}$ The influence of Alexander on Whitehead (who mentions Alexander only twice) seems to be justified as well. If this is true, then we may agree with Ellis who says that "even if it looks as though we have come a million miles in coming to Whitehead from Hegel, this line of descent at least achieves Hegel's intent." ${ }^{35}$ In other words, I think that despite all problems, nuances and incongruences between the Hegelian dialectic and the Whitehedian process that I described in this chapter, the claim

\footnotetext{
${ }^{30}$ Ibid., 409-10. Thus for Bradley the three steps of dialectic are: 1)undifferentiated feeling, 2) awareness that appearances are not real, 3) the realm of reality, the Absolute in which previous levels are reconstructed in higher synthesis.

${ }^{31}$ Samuel Alexander, Space, Time and Deity, 2 volumes, (London: Macmillan Co., 1920), http://books.google.com/books?id=OdbUxdAghF4C\&pg=PA1\&hl=pl\&source=gbs toc $r \& c a d=4 \# v=0$ =nepage\& q\&f=false, (access o6-11-2012), 6-8; Ellis, From Hegel to Whitehead, 412. Ellis refers also to Alexander's argument that we should abolish the terms Idealism and Realism. He says that no philosopher ever chooses just one of them, but rather stays in the middle. That would refer to Whitehead too.

${ }^{32}$ Alexander, Space, Time and Deity, vol. 1, 346, I quote after Ellis, From Hegel to Whitehead, 413.

${ }^{33}$ Ellis, From Hegel to Whitehead, 413-14.

${ }^{34}$ Whitehead, Process and Reality, xiii.

${ }^{35}$ Ellis, From Hegel to Whitehead, 418.
} 
about Whitehead being influenced by Hegelian metaphysics is legitimate, at least to a certain extent. ${ }^{36}$

But does this similarity refer to the notion of God and his relation to the world in Hegel and Whitehead as well? That is the main point in the second chapter of this article.

\section{Two Versions of Panentheism}

It is not difficult to indicate the main point of difference between classical theism (in Aquinas' exposition in particular) on the one side, and the Hegelian and Whitehedian understanding of God on the other. The demarcation line is the concept of God's simplicity, which serves as a ground for all key attributes described in the first part of the Summa Theologiae. For God's supreme perfection, goodness, eternity, immutability, omniscience and omnipotence, are all rooted in Aquinas' basic assertion that God is simple, that is free from any metaphysical compositions (form and matter, substance and accidents, essence and existence). Thus understood the concept of God's transcendence and independence of the world is complementary in Summa Theologiae with God's immanence, defined as his existence in everything "as an agent is present to that in which its action is taking place." According to Aquinas God is everywhere and "fills all places by giving existence to everything occupying those places." ${ }^{37}$

This understanding of God's nature was challenged by both Hegel and Whitehead. Although they want to preserve the dynamics of transcendence and immanence in God, nevertheless, they unanimously deny God's simplicity. The Hegelian Spirit unfolding in time and positing itself in Nature and Human Beings resembles the Whitehedian God dependent in his consequent nature on non-divine actual occasions. Implicit in their philosophy is the idea of God including the world in his being. Thus they embrace -

\footnotetext{
${ }^{36}$ In order to make this comparison between Hegelian and Whitehedian metaphysic more complete one should study two more issues: 1) the influence of British Romantic poetry of Coleridge and Wordsworth on Whitehead, and 2) a critical analysis of Whitehead's references to other philosophers, especially Locke and Hume. The first problem has been analyzed by Antoon Braeckman in "Whitehead and German Idealism: A Poetic Heritage," Process Studies 14, no. 4 (Winter 1985), 265-286; and mentioned by Ellis in From Hegel to Whitehead, 418. These problems require further study.

37 Thomas Aquinas, Summa Theologiae. Vol. 2: Existence and nature of God (Ia, 2-11), translated by Timothy McDermott O.P. (London: Blackfriars, 1964), Ia, Q. 8, a. 1, resp.; Ia, Q. 8, a. 2, resp.
} 
although none of them explicitly - a panentheistic notion of God-world relation. ${ }^{38}$ However, there are some important nuances and differences between them which are often lost in the application of their metaphysics to theology. We should try to bring them into discussion.

\subsection{Hegel as Panentheist}

Trying to present Hegel's concept of God, we begin usually with the reference to his Idea or Spirit which posits itself in Nature and Human Beings. This dialectical process, progressively realized in history, is for Hegel a necessary condition of God's full actuality. ${ }^{39}$ It is all true about the Hegelian God and gives us the right to regard him a father of contemporary proliferation of different versions of panentheism. However, that is not all that Hegel has to say about the God-world relation. There are some important characteristics of Hegelian philosophy of God that make his panentheism exceptional in comparison with other versions of this position.

In order to prove that the Spirit is dialectical in its nature, Hegel refers to the Christian doctrine of the Trinity, which becomes "the pictorialization of the first person of the Hegelian primary triad" in his all-embracing scheme. ${ }^{40}$ That his understanding of the Trinity is far from Christian orthodoxy, however, is unquestionable. McTaggart is right when he says that in Hegel "the Holy Ghost is the sole reality of the Trinity. In so far as

\footnotetext{
${ }^{38}$ Panentheism ('pan' = all, 'en' = in, 'Theos' = God), anticipated in Egyptian and Indian thought, was developed in philosophical and theological traditions throughout the centuries (Plato, Neoplatonism, Pseudo-Dionysius, Nicholas of Cusa). In 1828 panentheism was proposed and defined in its modern version by Karl Krause. He coined the term Allingottlehre, which is based on the assertion that everything is in God, who at the same time surpasses all that he created. Proponents of panentheism emphasize God's active presence in the world and place themselves in an opposition to the traditional theism, which they find as isolating God from the world. They reformulate understanding of classic attributes of God, such as omnipotence, omniscience, immutability, eternity and impassibility. Panentheism finds many followers among theologians and philosophers of God. Those who remain critical about panentheistic position refer usually to the problem of precise understanding of the preposition 'in' in the definition of panentheism, and the problem of God's immanence that seems to be overrated by panentheists at the expense of his transcendence. See John Culp, "Panentheism", The Stanford Encyclopedia of Philosophy (Summer 2009 Edition), Edward N. Zalta (ed.), http://plato.stanford.edu/archives/sum200g/entries/panentheism/, (access o6-11-2012).

${ }^{39}$ Brian Leftow, "God and the World in Hegel and Whitehead," in Hegel and Whitehead, 261.

${ }^{40}$ Robert C. Whittemore, "Hegel as Panentheist," Tulane Studies in Philosophy IX (1960), 149.
} 
the Father and the Son are real, they are moments in the nature of the Holy Ghost." ${ }^{41}$ Hegel refuses to acknowledge the precedence of the Father. The life and death of Jesus are merely an illustration of the incarnation which is realized not only in Christ, but in all that is finite. A fully true divinity for Hegel is the Spirit. ${ }^{42}$

Nevertheless, far as he is from orthodox Christianity, Hegel begins his meditation on the Trinity with the description of the Kingdom of the Father, which is a representation of God as the eternal Idea, a manifestation of God who "is, so to speak, outside of or before the creation of the world." 43 This eternal Idea obviously must posit itself in creation. Thus God is for Hegel strongly dependent on the existence of some world (only weakly dependent on the existence of this particular world). ${ }^{44}$ What is crucial for us, however, is that there is still in Hegel the notion of God in eternity, before creation. Consequently, we may say that in Hegel's metaphysics God is still the Creator of the universe. $^{45}$

This observation becomes an important argument in the discussion about the proper exposition of God's transcendence and immanence in panentheism. I think that Hegel's denial of God's simplicity makes it impossible for him to embrace a real ontological difference between God and creatures, which is for me the only proper expression of God's transcendence. Nonetheless, the notion of God before the creation is an important proof of his otherness in Hegelian philosophy of God. That justifies Leftow's interpretation of Hegel in which he says that Hegelian "idea is in a way common to God, and to the world as distinct from God, though only God can perceive this commonality. (...) Only divine or absolute experience perceives the fully actual Idea - for only in the attaining of such experience is the Idea fully real. Only divine or absolute experience

\footnotetext{
${ }^{41}$ John M. E. McTaggert, Studies in Hegelian Cosmology, (Cambridge: University Press, 1918), 204. I am indebted to Whittemore's presentation of McTaggert's interpretation of Hegelian thought in Hegel as Panentheist, 150.

42 Thus Hegel departs from classical Christian paradox of the tri-unity of three co-equal Persons. Whittemore presents a careful investigation of Hegelian Trinitarian triad based on his Lectures on the Philosophy of Religion. See Hegel as Panentheist, 147-162

${ }^{43}$ G. W. Hegel, Lectures on the Philosophy of Religion (3 vols.), translated by E. B. Spiers, J. B. Sanderson, (London: Kegan Paul, 1895), III, 7.

${ }^{44}$ Leftow, God and the World in Hegel and Whitehead, 262.

${ }^{45}$ Cooper, Panentheism. The Other God of the Philosophers, 114.
} 
perceives the world as fully one - for the world is fully one only in the existence of Absolute Spirit, and this existence is constituted by the having of experiences of the world as thus unified." ${ }^{46}$

This line of argumentation can be enriched and complemented by John Cooper's emphasis on the importance of divine freedom in Hegel. In his Philosophy of Right Hegel

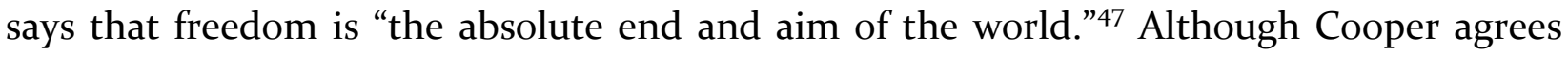
that in Hegelian metaphysics not having a world is not an option for God, he argues that Hegel holds a 'compatibilist' view of God's freedom. It is his dialectic that enables Hegel to attribute to God both determination and freedom - two sides of the same coin. ${ }^{48}$ Cooper's assertion can serve as another argument for God's transcendence in Hegel. It is also complementary with Leftow who once again comments on the Hegelian position and says that "if the world is for the sake of God, there is a strong though nonformal sense in which God's necessary properties are prior to, determine and render strongly dependent the world's necessary properties, and so its very existence." ${ }^{49}$

To sum up, I claim that Hegel is rightly regarded a founder of contemporary panentheism. In his dynamic metaphysics the whole universe is an incarnation of the Spirit. Thus Hegel realizes the first part of the basic panentheistic assertion which says that the world is in God. In my analysis I tried to explain the way in which Hegelian metaphysics also strives to meet the other requirement of panentheism, that is its emphasis on God's otherness from the universe. Nevertheless, I claim that the Hegelian concept of God-world relation - although departing significantly from classical theism - is still relatively close to the Thomistic understanding of divine causality. As we shall see, this position will prove to be somehow different in comparison with the one presented by Whitehead.

\subsection{Whitehead as Panentheist}

\footnotetext{
${ }^{46}$ Leftow, God and the World in Hegel and Whitehead, 261-62.

${ }^{47}$ G. W. Hegel, Philosophy of Right, translated by T. M. Knox (Oxford: Clarendon, 1942), section 129.

${ }^{48}$ Ibid.

${ }^{49}$ Leftow, God and the World in Hegel and Whitehead, 262-63.
} 
Studying the idea of the God-world relation in Hegel and Whitehead, one may think that it is exactly at this point that their metaphysical systems get as close as possible. For is not the Whitehedian concept of the primordial, consequent and superjective nature of God, a clear reference to the Hegelian dialectical triadic nature of God? Having this parallel in mind Leftow brings together metaphysical concepts proposed by both philosophers and says that "in each new phase of divine experience, God does (according to Whitehead) what (according to Hegel) God does over the course of world history: unify the concrete world with 'the nature of God before the world.' For both Hegel and Whitehead, the world becomes one in God's experiencing it." ${ }^{50}$ I find this statement questionable and far too optimistic. In what follows I will try to show some unique features of the Whitehedian concept of God which make his panentheism exceptional and different from the Hegel's.

Following his own general rule which says that "God is not to be treated as an exception to all metaphysical principles, (...) He is their chief exemplification," Whitehead places God among other actual entities. What distinguishes him is his non-temporal nature in which God prehends all eternal objects and does not perish. Thus God becomes the Ground of all possibilities in the world. This is the primordial, conceptual nature of God in which he has a subjective aim, that is to constitute eternal objects through concrescence into relevant lures of feeling (propositions of future novelty for prehending actual occasions). Thus understood, God is the "unlimited conceptual realization of the absolute wealth of potentiality." ${ }^{51}$ However, all these characteristics of the primordial nature of God do not make him a transcendent Creator of the universe. According to Whitehead "He is not before all creation, but with all creation." Moreover, in his primordial nature God is deficiently actual. Therefore we "must ascribe to him neither fullness of feeling, nor consciousness." ${ }^{22}$

\footnotetext{
${ }^{50}$ Ibid. 263.

${ }^{51}$ Whitehead, Process and Reality, 87-8, 343.

${ }^{52}$ Ibid., 343-44.
} 
This lack of perfection in God is fulfilled in his consequent nature which is "the physical prehension by God of the actualities of the evolving universe." ${ }^{\prime 3}$ That is the way in which the world is objectified in God who is now fully conscious. ${ }^{54}$ Thus, in a way similar to actual entities, God's nature is dipolar. But that is not all. Both primordial and consequent natures of God are finally sublated to the superjective nature of God which is "the character of the pragmatic value of his specific satisfaction qualifying the transcendent creativity in the various temporal instances." ${ }^{55}$ In order to understand this obscure definition one should refer to the concept of 'creativity' in Whitehead. God has satisfaction from qualifying the creativity. It turns out that creativity is the most basic category of the universe, conforming everything, including God. It is "the ultimate principle of novelty, ${ }^{56}$ (...) another rendering of the Aristotelian 'matter', and of the modern 'neutral stuff.' But it is divested of the notion of passive receptivity, either of 'form,' or of external relations." ${ }^{57}$ Although creativity is "conditioned by the objective immortality of the actual world", that is conditioned by God in whom all actual entities are objectified, "in the philosophy of organism the ultimate is termed 'creativity'; and God is its primordial, non-temporal accident. ${ }^{158}$

All this helps us to understand Whitehedian panentheism in which God seems to be devoid of almost all of transcendence. Because actual entities share with God the characteristic of self-causation, they can also transcend all other actual entities, including God. ${ }^{59}$ We read in Process and Reality that God is merely "the outcome of creativity, the foundation of order, and the goad towards novelty." ${ }^{60}$ Since actual entities constructing reality have the power of self-actualization (they decide themselves what they prehend), God ceases to be the Creator of the universe which itself is everlasting. All he can do is propose which eternal objects each actual entity should prehend in the future, and give to

\footnotetext{
${ }^{53}$ Ibid, 88.

${ }^{54}$ Ibid., 345 .

${ }^{55}$ Ibid., 88.

${ }^{56}$ Ibid., 21.

${ }^{57}$ Ibid., 31.

${ }^{8}$ Ibid., 7, 31.

${ }^{59}$ Ibid., 222.

${ }^{60}$ Ibid., 88.
} 
it an objective immortality in his consequent nature. ${ }^{61}$ This Witehedian version of panentheism can be summarized with the famous quote from Process and Reality in which he says that "God does not create the world, he saves it: or, more accurately, he is the poet of the world, with tender patience leading it by his vision of truth, beauty, and goodness." ${ }^{62}$

\subsection{The Hegelian and the Whitehedian Panentheisms compared}

In the conclusion of this chapter I will now compare the two versions of panentheism described above. I will start with the differences, as they are more evident. They refer mainly to the crucial issue for panentheism in its dispute with classical theism, that is the relation between God's transcendence and immanence.

Like all panentheists, both Hegel and Whitehead struggle to defend God's otherness. From what has been said one can see that the Hegelian God is more transcendent. He is still the Creator who can be conceived before the existence of the world. We also saw that Hegel's dialectic helps to save God's freedom. On the contrary, the Whitehedian God is less free, as he has to necessarily prehend and objectify in his consequent nature all actual occasions. He is not a creator anymore, but rather a part of the atomistic system of the universe. There is no creatio ex nihilo. This limitation of God's role in his relation to the world is well-described by Leftow who says: "While in Hegel the world is for God and God is for nothing beyond Himself, in Whitehead God and the world are for the sake of each other, and both are 'instruments' of Creativity." ${ }^{63}$ Gregerson goes even further and says that "[o]n this point there is hardly a mediation possible between Hartshorne and the understanding of divine causality in the Abrahamic tradition, which was also presupposed by Hegel. The point of demarcation is whether creativity derives from God the creator or belongs to the everlasting world." ${ }^{64}$

\footnotetext{
${ }^{61}$ This is the way in which Whitehedian philosophy of God becomes panentheistic (all is in God).

${ }^{62}$ Whitehead, Process and Reality, 345.

${ }^{63}$ Leftow, God and the World in Hegel and Whitehead, 264.

${ }^{64}$ Niels Henrik Gregersen, "Three Varieties of Panentheism," in In Whom We Live and Move and Have Our Being, 33 .
} 
The limitation of God's transcendence in Whitehead's philosophy finds another expression in the fact that God can only provide the stimulus for actual activities prior to their act of prehension, and absorb worldly events after their occurrence. He cannot be present simultaneously with actual entities in the act of their concrescence. In other words, not only does Whitehead reject creatio ex nihilo, but his understanding of creatio continua departs from the one offered in classical theism as well. ${ }^{65}$ However, I do not want to claim that the Whitehedian God is not transcendent at all. William Christian presents a whole set of arguments explaining how God transcends the world in Whitehead. He argues that in spite of everything being in process God is free, has his own subjective immediacy and is perfect in scope, quality and intensity of his experience. ${ }^{66} \mathrm{I}$ do not agree with the first argument he presents, but I concur that there are ways in which it is possible to defend God's transcendence in the philosophy of organism. Nevertheless, one is sure, that Whitehead is further away than Hegel from the classical theistic understanding of God and his relation to the world, and that his God is less transcendent than that of Hegel.

But there are also some points of convergence between these two versions of panentheism. After all, as we have seen, there are many important similarities and influences of Hegelian metaphysics on the Whitehedian philosophy of organism. Therefore, if God (the Spirit) and his subjectivity is the basic metaphysical category in Hegel, he cannot be neglected and marginalized in Whitehead. In his system each actual occasion embodies God and is embodied in God. That obviously resembles the Hegelian idea of the Absolute unfolding itself in the world. The three natures of God in the philosophy of process are somehow related to Hegel's dialectic as well. Finally, the objectification of the world in God in Whitehead's thought can be compared with the synthesis in God's dialectic triad in Hegel. God posits himself in the world which is eventually sublated to the ultimate 'Real'. Being a part of this 'ultimate reality' gives the Hegelian world what Whitehead would call an objective immortality.

\footnotetext{
${ }_{5}$ "To the mind of God, actual occasions remain black boxes." - says Gregersen referring to William Reese and his The Philosophy of Hartshorne. See Niels Henrik Gregersen, Three Varieties of Panentheism, 33.

${ }^{66}$ William A. Christian, An Interpretation of Whitehead's Metaphysics, (New Haven: Yale University Press, 1959), chapter 18: "God and the World: Transcendence and immanence."
} 
This comparison of the two versions of panentheism shows how many aspects one should take into account when choosing this position as a basis for theological endeavor. Here I side with Gregersen when he says that "anyone who wants to describe himself or herself as a panentheist should from the outset make clear what kind of panentheism he or she is endorsing." ${ }^{67}$ That brings us to the last chapter of this article.

\section{Panentheism in the Science-Theology Dialogue}

Knowing the points of convergence and divergence between Hegelian and Whitehedian panentheism as described above, I will now try to trace the presence of these two philosophical traditions within the framework of the science/theology dialogue in the Anglo-American context. I will refer to Barbour, Peacocke, and Clayton.

\subsection{Ian Barbour}

Focusing his research on the philosophical and theological implications of quantum mechanics, the theory of relativity, the big bang theory, evolutionary biology and genetics, Ian Barbour criticizes classical theism and accepts the proposition of panentheism. Significantly, Barbour does not refer to the Hegelian roots of this concept in its contemporary versions. On the other hand, he willingly accepts the Whitehedian tradition and uses it to shape his own understanding of the God-world relation. But the way Barbour applies process thought in his own research is very specific. His writings show that along with the reference to Whitehead himself, Barbour finds a philosophical continuation of his thought presented by Hartshorne very important, along with some theological interpretations of Whitehead presented by Cobb and Griffin.

Naturally, Barbour begins with reference to basic concepts of the philosophy of organism such as: the primacy of time, the interconnection of events, reality understood as organic process, the self-creation of every entity. ${ }^{68}$ Consequently, in his description of God's nature, Barbour is first rooted in Whitehead's analysis of the primordial and consequent nature of God. But it is the idea of God's relatedness and his being influenced by events taking place in the world, elaborated by Hartshorne, that became the first point

\footnotetext{
${ }^{67}$ Gregersen, Three Varieties of Panentheism, 34

${ }^{68}$ Barbour, Religion and Science, 285-87.
} 
of emphasis for Barbour and influenced him the most. For it was in close reference to Hartshorne's Divine Relativity that Barbour said of God in his Religion and Science: "God is not merely influenced by the world; God is 'infinitely sensitive' and 'ideally responsive.' Divine love is supremely sympathetic participation in the world of process." ${ }^{69}$ Barbour also embraces the concept of the dipolar God which again - introduced by Whitehead ${ }^{70}$ - was elaborated by Hartshorne. ${ }^{71}$

I think that Barbour, attracted by the idea of divine relativity and the reformulation of God's attributes in Hartshorne, does not pay enough attention to some crucial issues challenging the Whitehedian tradition of philosophy of God. Although he mentions the problem of God's transcendence in process thought ${ }^{72}$, he defends Whitehead and claims that the transcendent part of God's nature is still strongly represented in his philosophy. He seems to accept at the same time the idea of God being merely one factor among others, and Whitehead's rejection of creatio ex nihilo. ${ }^{73}$ That these issues are problematic in Whithehead not only in reference to the classical theism but also in comparison with other versions of panentheism, I tried to show above.

I also believe that Barbour is wrong when, in defense of God's transcendence in Whitehead, he claims that "Whitehead attributes to God the all-decisive role in the creation of each new occasion, namely provision of its initial aim." ${ }^{74}$ The notion of 'creativity' as the ultimate category in Whitehead and his idea of God being an "outcome of creativity", although primordial and non-temporal - but still merely an 'accident,' shows that God cannot have a decisive role in the becoming of the world in Whitehead's system. ${ }^{75}$ I believe that the comparison of the Hegelian and Whitehedian metaphysics

\footnotetext{
${ }^{69}$ Ibid., 294; Charles Hartshorne, The Divine Relativity, (New Haven and London: Yale University Press, 1964), chapter 2: "God as Absolute, Yet Related to All," 6o-94.

${ }^{70}$ Whitehead, Process and Reality, 348.

${ }^{71}$ Hartshorne, The Divine Relativity, chapter 3: "The Divine Attributes as Types of Social Relationship," 11658.

${ }^{72}$ Barbour, Religion and Science, 326.

${ }^{73}$ Ibid., 295.

${ }^{74}$ Ibid., 296.

75 Gene Reeves lists four formative elements in the creation of actual occasions in Whitehead: past occasions, eternal objects, creativity and God. He refers to Cobb arguing that God has always the decisive reason that each new occasion becomes. Barbour's position is likewise. Reeves raises the same objection that I presented above. If creativity is 'the ultimate' in Whitehead, the claim that God is still the decisive factor is
} 
sheds a new light on the problem of God's transcendence in panentheism, and it might be helpful in redefining Barbour's application of Whitehedian panentheism in his science/theology discussion. I think it may be possible for Barbour to keep the notion of God's relativity and return to a more traditional (perhaps Hegelian) understanding of God's nature and creativity. This may enable him to better defend the notion of God transcendence in his version of panentheism.

\subsection{Arthur Peacocke}

The method presented by Arthur Peacocke in his writings on theology and science raises some important questions. Like other authors in the field, Peacocke shaped his theology with respect to the knowledge of the world that is given in natural sciences. Being a biochemist, he perceived the world as a complex and dynamic system of countless interactions inside and between different levels of organization of matter. He emphasized the importance of the emergence of complexity, the role of necessity and chance, and both top-down and bottom-up causation. Similar to others he also claimed that this notion of the world provided by natural sciences challenges our faith. Thus, he opted for a radical reformulation of God's attributes and the concept of his relation to the world. ${ }^{76}$

What is exceptional about Peacocke's theology is that in order to reshape our concept of God, he embraces panentheism, but at the same time distances himself from any philosophical framework for this position. Knowing that his theology is regarded as being close to the process tradition of thought, Peacocke claims that panentheism as such is "not at all dependent on that particular metaphysical system." does not offer any other philosophical point of reference or source for his panentheism.

I find the position presented by Peacocke highly debatable. In my opinion it is hard to ignore the whole philosophical analysis and discussion of God's transcendence and

simply contradictory. See Gene Reeves, "God and Creativity," in Explorations in Whitehead's Philosophy, edited by Lewis S. Ford and George L. Kline, (New York: Fordham University Press, 1983), 239-51.

${ }^{76}$ A. Peacocke, Theology for a Scientific Age. Being and Becoming - Natural, Divine, and Human, (Minneapolis: Fortress Press, 1990), the second part of the book. See also chapters: 3 (The world as it is) and 4 (The world in process) in: A. Peacocke, Paths From Science Towards God, (Oxford: Oneworld, 2001), 39-90; and the first part (The World of Science) of the article: A. Peacocke, "Articulating God's Presence in and to the World Unveiled by the Sciences," in In Whom We Live and Move and Have Our Being, 138-43.

${ }^{77}$ Peacocke, Theology for a Scientific Age, footnote no. 75, page 371-2. 
immanence in the context of the philosophical notion of panentheism. After all, these problems are at the very heart of the definition of panentheism and are crucial for its application in theology.

\subsection{Philip Clayton}

The position presented by Philip Clayton is very interesting. As a philosopher he knows and elaborates quite well on the whole trajectory in modern thought leading to the philosophy of subject and panentheism in German Idealism. ${ }^{78} \mathrm{He}$ also knows the Whitehedian philosophy of process and his version of panentheism. It seems that Clayton wants to bring these two traditions together, and he does it in a very specific way.

Clayton values the long tradition of continental philosophy. That is why, when embracing panentheism, he refers first to German Idealism. But surprisingly, it is not Hegel that would become for Clayton the main point of reference. In the last chapter of The Problem of God in Modern Thought he expresses his commitment to Shelling and his idea of a personal God, choosing freely to create and thus self-manifesting himself, having history and destiny, growing and developing in time. ${ }^{79}$ Clayton finds Hegel too close to the Aristotelian tradition, especially the idea of the first principle, which conditions all entities without being conditioned by them. ${ }^{80}$ He says that this is a typical position accepted by different philosophers of the Absolute, such as Hegel. ${ }^{81}$ What he disapproves of in Hegelian metaphysics is the necessity with which the Absolute has to posit itself in creation, a requirement of the system of which the Absolute is an indispensable part. He goes on to say that being close to this tradition Hegel "fails to preserve the contingency and the mystery of the decision to create." ${ }^{82}$ That is why Clayton prefers Schelling's personal notion of God and his focus on freedom. ${ }^{83}$ Clayton's distancing himself from the Aristotelian tradition is symptomatic and explains the next step he takes.

\footnotetext{
${ }^{78}$ Clayton, Panentheism in Metaphysical and Scientific Perspective, 77-81.

${ }^{79}$ Philip Clayton, The Problem of God in Modern Thought, (Grand Rapids: Eerdmans, 2000), 467-505. Cooper names Clayton's theology a "neo-Schellingian emergent personalist panentheism (Cooper, 314).

${ }^{80}$ See point 2.1.

${ }^{81}$ Clayton, The Problem of God in Modern Thought, 370.

${ }^{82}$ Ibid., 235, 210.

${ }^{83}$ Ibid., 498-505
} 
In his search for a notion of God more personal then Hegel's Absolute, Clayton sides not only with Shelling. In God and Contemporary Science he refers to the philosophy of organism. I think he does it mainly because of the emphasis on God's affectivity and reciprocity in process thought. This notion matches his stressing the personal character of God's nature. ${ }^{84} \mathrm{He}$ also sides with the process concept of dipolar God which he finds first present in Schelling's idealism. ${ }^{85}$ However, Clayton mentions the philosophy of organism only occasionally and does not address the whole problem of God's transcendence and immanence in Whitehead, of which he must be aware as a philosopher. Nor does he go deeper into an analysis of differences between Whitehead and those who further developed his thought. These are important shortcomings of his position. Nevertheless, it is significant that Clayton, when choosing panentheism, refers to both philosophical traditions analyzed in this article. Moreover, his position shows that there are some subtle differences and nuances among various versions of panentheism, not only in the comparison of dialectical and process thought, but also within German Idealism itself (Hegel contra Schelling).

\section{Conclusion}

The aim of this article was threefold. In the first part I presented a critical analysis of possible similarities and differences between Hegel's metaphysic of dialectic and Whitehead's philosophy of organism. I think that as builders of philosophical systems, departing from substance to subject, and emphasizing the dynamic character of reality, they both can be regarded as proponents of philosophical concepts that are similar to a certain extent. Although the comparison of the mechanism of dialectic and process raises some critical questions, it seems possible that the Hegelian metaphysics, transmitted and transformed by British Idealists, reached Whitehead and influenced his philosophy of organism. I claim that the notion of this trajectory is of a great importance for those who accept the philosophy and theology of process.

\footnotetext{
${ }^{84}$ Clayton, God and Contemporary Science, 94.

${ }^{85}$ Clayton, The Problem of God in Modern Thought, 483-86; God and Contemporary Science, 93-6.
} 
The second part of the article was dedicated to philosophical panentheism in its two versions presented by Hegel and Whitehead. I tried to show particular nuances, divergences and convergences between these two philosophers. The level at which Hegel and Whitehead differ in their departure from the classical Thomistic understanding of divine causality and the God-world relation is significant. It has a great influence on the understanding of God's transcendence and immanence in their philosophical systems. I think that all this cannot be ignored by those who embrace the panentheistic position as a metaphysical background for their theological work.

The final part of the article, brought to discussion three main authors referring to panentheism in the contemporary science/theology debate in the Anglo-American context. I found the process version of panentheism to be more popular in these circles. Barbour embraces it wholeheartedly. Clayton introduces it as a point of reference in his analysis based on Shelling's metaphysics. Peacocke - although he distances himself from Whitehead and his successors - seems to be close to the philosophy of organism as well. The notion of Hegel's panentheism is much less present in the thought of those involved in the science/theology dialogue. What I found particularly missing among the participants of this debate was a deeper study and analysis of possible similarities and dissimilarities between Hegel and Whitehead. This lacuna is especially noticeable regarding the problem of God's transcendence and immanence, which seems to be crucial for every panentheist.

I tried to show in this article that there is an important level of resemblance between process and Hegelian metaphysics. I hope that the awareness of this fact will be helpful for those who choose panentheism as the philosophical ground for their understanding of God and his relation to the world.

\section{BIBLIOGRAPHY}

\section{$\underline{\text { Primary Sources }}$}


Alexander, Samuel, Space, Time and Deity, 2 volumes. London: Macmillan Co., 1920, http://books.google.com/books?id=OdbUxdAghF4C\&pg=PA1\&hl=pl\&source=gbs toc $\quad \mathrm{r} \& \mathrm{c}$ $\underline{\mathrm{ad}=4 \# \mathrm{v}=\text { onepage } \& \mathrm{q} \& \mathrm{f}=\text { false, }}$ (access o6-11-2012).

Aquinas, Thomas, Summa Theologiae. Vol. 2: Existence and nature of God (Ia, 2-11), translated by Timothy McDermott O.P. London: Blackfriars, 1964.

Barbour, Ian G., Religion and Science. Historical and Contemporary Issues. New York: HarperCollins Publishers, 1997.

Bradley, F. H., Appearance and Reality. London: Swan Sonnenschein \& Co., 1902.

Clayton, Philip, "Panentheism in Metaphysical and Scientific Perspective." In In Whom We Live and Move and Have Our Being. Panentheistic Reflections on God's Presence in a Scientific World, edited by Philip Clayton and Arthur Peacocke, 73-91. Grand Rapids, Michigan/Cambridge, U.K.: William B. Eerdmans Publishing Company, 2004.

Clayton, Philip, God and Contemporary Science. Grand Rapids: Eerdmans Publishing Company, 1997.

Clayton, Philip, The Problem of God in Modern Thought. Grand Rapids: Eerdmans, 2000.

Hartshorne, Charles, The Divine Relativity. New Haven and London: Yale University Press, 1964.

Hegel, Georg Wilhelm, Lectures on the History of Philosophy Vol. III, translated by E. S. Haldane and Frances H. Simson. London: Routledge \& Kegan Paul LTD, 1955

Hegel, Georg Wilhelm, Lectures on the Philosophy of Religion (3 vols.), translated by E. B. Spiers, J. B. Sanderson. London: Kegan Paul, 1895.

Hegel, Georg Wilhelm, Logic, translated by William Wallace. Oxford: Clarendon Press, 1894 .

Hegel, Georg Wilhelm, Philosophy of Right, translated by T. M. Knox (Oxford: Clarendon, 1942)

Hegel, Georg Wilhelm, The Phenomenology of Mind, translated by J.B. Baillie. London: George Allen \& Unwin LTD, 1931.

Peacocke, Arthur, "Articulating God's Presence in and to the World Unveiled by the Sciences." In In Whom We Live and Move and Have Our Being. Panentheistic Reflections on God's Presence in a Scientific World, edited by Philip Clayton and Arthur Peacocke, 137-54. Grand Rapids, Michigan/Cambridge, U.K.: William B. Eerdmans Publishing Company, 2004 . 
Peacocke, Arthur, Paths From Science Towards God. Oxford: Oneworld, 2001.

Peacocke, Arthur, Theology for a Scientific Age. Being and Becoming - Natural, Divine, and Human. Minneapolis: Fortress Press, 1990.

Whitehead, Alfred North, Process and Reality. New York: The Free Press, 1985.

Whitehead, Alfred North, Essays in Science and Philosophy, (London: Rider \& Co., 1948).

\section{$\underline{\text { Secondary Sources }}$}

Braeckman, Antoon, "Whitehead and German Idealism: A Poetic Heritage," Process Studies 14, no. 4 (Winter 1985): 265-286.

Brierley, Michael W., "Naming a Quiet Revolution: The Panentheistoc Turn in Modern Theology." In In Whom We Live and Move and Have Our Being. Panentheistic Reflections on God's Presence in a Scientific World, edited by Philip Clayton and Arthur Peacocke, 1-15. Grand Rapids, Michigan/Cambridge, U.K.: William B. Eerdmans Publishing Company, 2004 .

Christian A., Williams, An Interpretation of Whitehead's Metaphysics. New Haven: Yale University Press, 1959.

Cooper, John W., Panentheism. The Other God of the Philosophers. Grand Rapids, Michigan: Baker Academic, 2006.

Culp, John, "Panentheism", The Stanford Encyclopedia of Philosophy (Summer 2009 Edition), Edward N. Zalta (ed.), http://plato.stanford.edu/archives/sumzoog/entries/panentheism/, (access o6-11-2012).

Ellis, Robert, “From Hegel to Whitehead," Journal of Religion 61, no. 4 (Oct. 1981): 403-421.

Forster, Michael, “Hegel's Dialectical Method." In The Cambridge Companion to Hegel, edited by Frederick C. Beiser, 130-17o. New York, Cambridge: Cambridge University Press, 1993.

Gregersen, Niels Henrik, "Three Varieties of Panentheism." In In Whom We Live and Move and Have Our Being. Panentheistic Reflections on God's Presence in a Scientific World, edited by Philip Clayton and Arthur Peacocke, 19-35. Grand Rapids, Michigan/Cambridge, U.K.: William B. Eerdmans Publishing Company, 2004.

Harris, Errol E., "The Contemporary Significance of Hegel and Whitehead." In Hegel and Whitehead. Contemporary Perspectives on Systematic Philosophy, edited by George R. Lucas, JR. New York: State University of New York Press, 1986. 
Hartmann, Klaus, "Types of Explanation in Hegel and Whitehead." In Hegel and Whitehead. Contemporary Perspectives on Systematic Philosophy, edited by George R. Lucas. New York: State University of New York Press, 1986.

Kline, George L., "Concept and Concrescence: An Essay in Hegelian-Whitehedian Ontology." In Hegel and Whitehead. Contemporary Perspectives on Systematic Philosophy, edited by George R. Lucas. New York: State University of New York Press, 1986.

Leftow, Brian "God and the World in Hegel and Whitehead." In Hegel and Whitehead. Contemporary Perspectives on Systematic Philosophy, edited by George R. Lucas. New York: State University of New York Press, 1986.

Lowe, Victor, Understanding Whitehead. Baltimore: The Johns Hopkins Press, 1966.

Lucas, George R., "Hegel, Whitehead, and the Status of Systematic Philosophy." In Hegel and Whitehead. Contemporary Perspectives on Systematic Philosophy, edited by George R. Lucas, JR. New York: State University of New York Press, 1986.

Lucas, Hans-Christian, “Spinoza, Hegel, Whitehead: Substance, Subject, and Superject." In Hegel and Whitehead. Contemporary Perspectives on Systematic Philosophy, edited by George R. Lucas. New York: State University of New York Press, 1986.

Reeves, Gene, "God and Creativity." In Explorations in Whitehead's Philosophy, edited by Lewis S. Ford and George L. Kline. New York: Fordham University Press, 1983.

Russel, Robert John, “The theological-scientific vision of Arthur Peacocke,” Zygon 26, no. 4 (December 1991): 505-17.

Sprigge T. L. S., The God of Metaphysics. Oxford: Clarendon Press, 2006.

McTaggert, John M. E., Studies in Hegelian Cosmology. Cambridge: University Press, 1918.

Ushenko, A. P., "Negative Prehension," The Journal in Philosophy 35, no. 10 (May 1937): 263-267.

Veken, Jan Van der, "A Plea for an Open, Humble Hegelianism." In Hegel and Whitehead. Contemporary Perspectives on Systematic Philosophy, edited by George R. Lucas. New York: State University of New York Press, 1986.

Welker, Michael, "Hegel and Whitehead: Why Develop a Universal Theory?" In Hegel and Whitehead. Contemporary Perspectives on Systematic Philosophy, edited by George R. Lucas. New York: State University of New York Press, 1986.

Ward, Keith, "The World as the Body of God." In In Whom We Live and Move and Have Our Being. Panentheistic Reflections on God's Presence in a Scientific World, edited by Philip Clayton and Arthur Peacocke, 62-72. Grand Rapids, Michigan/Cambridge, U.K.: William B. Eerdmans Publishing Company, 2004. 
Whittemore, Robert C., "Hegel as Panentheist," Tulane Studies in Philosophy IX (1960): 134-64.

Whittemore, Robert C., "Hegel's 'Science' and Whitehead's 'Modern World'," Philosophy 31, no. 116 (Jan. 1956): 36-54. 